\title{
PENGARUH KUALITAS PRODUK, PERSEPSI HARGA DAN PROMOSI MEDIA LUAR RUANG TERHADAP KEPUTUSAN PEMBELIAN LAPIS TALAS SANGKURIANG
}

\author{
Oleh: \\ Tjiauw Reza Anthony Wijaya \\ E-mail: Rezapearl@gmail.com \\ Angga Sulistiono
}

\begin{abstract}
ABSTRAK
Penelitian ini bertujuan untuk menganalisis Pengaruh Kualitas Produk, Persepsi Harga, Dan Promosi Media Luar Ruang Terhadap Keputusan Pembelian. Penelitian ini dilakukan pada produk Lapis Talas Sangkuriang di Bogor. Populasi dalam penelitian ini adalah mahasiswa yang pernah mengkonsumsi Lapis Talas Sangkuriang. Sample ditentukan dengan metode purposive sampling dan jumlah responden ditentukan sebanyak 100. Pengumpulan data dilakukan dengan cara memberikan kuesioner kepada responden, tentang Pengaruh Kualitas Produk, Persepsi Harga, Dan Promosi Media Luar Ruang Terhadap Keputusan Pembelian. Penelitian ini diolah menggunakan SPSS Regresi Berganda. Hasil penelitian ini adalah (1) Kualitas Produk memiliki pengaruh positif dan signifikan terhadap Keputusan Pembelian, dengan hasil nilai koefisien sebesar 0,306 dan nilai t-statistik sebesar 6,147 (>1,661). (2) Persepsi Harga memiliki pengaruh positif dan signifikan terhadap Keputusan Pembelian, dengan hasil nilai koefisien sebesar 0,219 dan nilai t-statistik sebesar 2,989 (>1,661). (3) Promosi Media Luar Ruang memiliki pengaruh positif dan signifikan terhadap Keputusan Pembelian, dengan hasil nilai koefisien sebesar 0,128 dan nilai t-statistik sebesar 3,215 (>1,661). (4) Kualitas produk, persepsi harga dan promosi media luar ruang berpengaruh positif terhadap keputusan pembelian dibuktikan dengan uji simultan $f$ tabel $120.458>$ dari $f$ tabel 2.70 .

Kata Kunci: Kualitas Produk, Persepsi Harga, Promosi Media Luar Ruang Dan Keputusan Pembelian.
\end{abstract}




\section{PENDAHULUAN}

Era globalisasi menjanjikan suatu peluang dan tantangan bisnis baru bagi perusahaan yang beroperasi di Indonesia. Disatu sisi era globalisasi memperluas pasar produk dari perusahaan di Indonesia. Keadaan ini memunculkan persaingan yang semakin ketat baik antar perusahaan domestik maupun perusahaan asing. Kondisi persaingan yang ketat ini menyebabkan perusahaan harus memiliki sebuah kemampuan adaptasi bisnis yang tangguh dalam lingkungan bisnis yang dinamis (Setiawan, 2018).

Fenomena persaingan di era globalisasi akan semakin mengarahkan sistem perekonomian negara manapun ke mekanisme pasar yang pada akhirnya memposisikan pemasar untuk selalu mengembangkan dan merebut pangsa pasar (market share). Salah satu aset untuk mencapai hal itu adalah merek produk yang dewasa ini berkembang menjadi sumber aset terbesar bagi suatu perusahaan. Dalam kondisi pasar yang kompetitif, preferensi dan loyalitas pelanggan adalah kunci kesuksesan. Dengan demikian, pemasaran dewasa ini merupakan pertempuran produk.
Produk hanya memiliki manfaat fungsional, sedangkan merek mampu menjelaskan emosi serta hubungan secara spesifik dengan pelanggannya karena mengandung nilai-nilai emosional, keyakinan, harapan dan persepsi pelanggannya. Ketika teknologi menjadi semakin setara, maka produk dengan mudah dapat ditiru oleh pesaing, sementara merek lebih sulit ditiru karena keunikannya.

Dari perspektif di atas, maka dapat diambil kesimpulan bahwa merek pada dasarnya mengandung nilai-nilai potensial yang sangat strategis bagi perusahaan dalam menghadapi persaingan bisnis. Nilai ini kemudian oleh banyak pakar didefinisikan ekuitas merek. Dalam dunia bisnis yang semakin kompetitif saat ini, perusahaan dituntut untuk bisa memenuhi keinginan konsumen, sehingga diharapkan konsumen akan menjadi loyal terhadap merek perusahaan tersebut. Brand loyalty (loyalitas merek) merupakan suatu ukuran keterkaitan pelanggan terhadap sebuah merek. Ukuran ini mampu memberikan gambaran tentang mungkin tidaknya seorang pelanggan beralih ke merek produk yang lain. Seorang pelanggan yang 
sangat loyal pada suatu merek tidak akan dengan mudah memindahkan pembeliannya ke merek yang lainnya yang sejenis, apapun yang terjadi dengan merek tersebut.

\section{Suatu produk dapat} mempunyai kesadaran merek yang tinggi, kualitas yang baik, asosiasi yang cukup banyak tetapi belum tentu mempunyai loyalitas merek yang tinggi. Sebaliknya produk yang mempunyai loyalitas merek yang tinggi dapat dipastikan memiliki kesadaran merek yang tinggi, kualitas yang bagus, dan asosiasi yang cukup dikenal. Dengan kata lain, kondisi ini akan membentuk perceived quality yang optimal dalam membentuk kepuasan pelanggan (Setiawan, 2014)

Ekuitas merek merupakan nilai yang terpenting bagi para pemasar karena mewakili perusahaan untuk menjelaskan kepada konsumen bahwa produk mereka adalah yang terbaik. Jika perusahaan memiliki merek popular dan merek itu dipandang baik oleh pasar sasaran, maka hal itu akan menjadi kemenangan dalam persaingan yang sengit. Bagi perusahaan yang sadar akan makna penting dari strategi merek, ekuitas merek menjadi hal yang selalu diperhatikan dan pengukurannya dilakukan secara teratur, karena ekuitas merek dapat dianggap sebagai tambahan arus kas yang diperoleh melalui pengaitan nama merek dengan produk atau jasa yang mendasarinya.

Sedemikian pentingnya peran ekuitas merek sebagai landasan dalam menentukan langkah dan strategi perusahaan dari suatu produk sehingga sering kali ekuitas merek memperoleh kajian yang mendalam. Merek yang prestisius dapat memiliki brand equity yang kuat. Suatu produk dengan merek yang kuat dapat membentuk landasan merek (brand platform) yang kuat dan mampu mengembangkan keberadaan suatu merek dalam persaingan apapun dalam jangka waktu yang lama.

Hal ini dapat tercapai apabila perusahaan melakukan usaha-usaha yang optimal dalam mengukur, memelihara, melindungi dan menjaga ekuitas merek. Jika hal ini dilakukan maka akan dapat dirasakan pengaruh brand equity tersebut terhadap pangsa pasarnya. Hal ini di masa depan akan membentuk pada kepercayaan konsumen yang kuat (Meiliana \& Setiawan, 2013). 
Nilai ekuitas suatu merek adalah menjadi permasalahan dalam penelitian ini. Produk Kue Bolu Lapis Talas Sangkuriang dipilih menjadi objek penelitian ini karena tergolong sebagai convenience product. Keputusan pembelian dalam consumer goods yang tergolong sebagai convenience product sangat dipengaruhi oleh merek produk tersebut. Sebab pada produk jenis tersebut faktor-faktor yang terkait dengan atribut produk menjadi kurang berpengaruh dalam keputusan pembelian, sehingga mereklah yang menjadi faktor utama dalam pengambilan keputusan pembelian oleh konsumen.

Adapun identifikasi masalah yang dapat ditemukan, antara lain sebagai berikut :

1. Apakah kualitas produk berpengaruh terhadap keputusan pembelian?

2. Apakah persepsi harga berpengaruh terhadap keputusan pembelian?

3. Apakah promosi media luar ruang berpengaruh terhadap keputusan pembelian?

4. Apakah kualitas produk, harga dan promosi media luar ruang secara bersama-sama berpengaruh terhadap keputusan pembelian?

Adapun tujuan penelitian secara khusus adalah untuk mendapatkan jawaban dari permasalahan yang diidentifikasikan diatas, yaitu :

1. Untuk mengetahui pengaruh kualitas produk terhadap keputusan pembelian Lapis Talas Sangkuriang.

2. Untuk mengetahui pengaruh persepsi harga terhadap keputusan pembelian Lapis Talas Sangkuriang.

3. Untuk mengetahui pengaruh promosi media luar ruang terhadap keputusan pembelian.

4. Untuk mengetahui pengaruh kualitas pelayanan, harga dan promosi media luar ruang secara bersama-sama terhadap keputusan pembelian Lapis Talas Sangkuriang.

\section{TINJAUAN PUSTAKA}

Machfoedz (2010) mengemukakan bahwa pengambilan keputusan adalah suatu proses penilaian dan pemilihan dari berbagai alternatif sesuai dengan kepentingankepentingan tertentu dengan 
menetapkan suatu pilihan yang dianggap paling menguntungkan. Menurut Swashta dan Handoko (2008) mengemukakan bahwa "Keputusan pembelian merupakan proses dalam pembelian yang nyata, apakah membeli atau tidak". Swastha dan Irawan (2008) mengemukakan keputusan konsumen adalah motif atau dorongan yang timbul terhadap sesuatu dimana pembeli melakukan pembelian disebabkan adanya kebutuhan dan keinginan.

Menurut Saladin (2007), "Produk adalah segala sesuatu yang dapat ditawarkan ke suatu pasar untuk diperhatikan, dimiliki, dipakai atau dikonsumsi sehingga dapat memuaskan keinginan dan kebutuhan". Sedangkan Menurut Kotler (2005), "Kualitas produk adalah keseluruhan ciri serta dari suatu produk atau pelayanan pada kemampuan untuk memuaskan kebutuhan yang dinyatakan/ tersirat".

\section{Menurut Schiffman \& Kanuk (2007) persepsi adalah suatu proses seorang individu dalam menyeleksi, mengorganisasikan, dan menterjamahkan stimulus-stimulus informasi yang datang menjadi suatu gambaran yang menyeluruh. Persepsi}

mempunyai pengaruh yang kuat bagi konsumen. Salah satu faktor yang berpengaruh terhadap konsumen yaitu persepsi akan harga.

Dalam konteks pemasaran, menurut Kotler dan Garry Amstrong (2013) istilah harga dapat diartikan sebagai jumlah uang yang dibebankan untuk sebuah produk atau jasa atau jumlah nilai konsumen dalam pertukaran untuk mendapatkan manfaat dan memiliki atau menggunakan produk atau jasa.

Media adalah segala bentuk apapun yang bisa menghantarkan pesan dari pemilik pesan ke penerima pesan. Luar ruang adalah lokasi penempatan bentuk penghantar pesan, yaitu berada di luar ruangan atau di luar rumah. Menurut Fandy Tjiptono (2008) "Media Luar Ruang adalah media yang berukuran besar dipasang di tempat-tempat terbuka seperti dipinggir jalan, dipusat keramaian atau tempat-tempat khusus lainnya, seperti di dalam bus kota, gedung, pagar tembok, dan sebagainya".

\section{METODOLOGI PENELITIAN}

Metode yang digunakan dalam penelitian ini adalah metode penelitian 
kuantitatif. Metode kuantitatif adalah metode penelitian yang berlandaskan pada sampel filsafat positivisme, pengumpulan data menggunakan instrumen penelitian, analisis data bersifat kuantitatif/statistik, dengan tujuan untuk menguji hipotesis yang telah diciptakan. Variabel penelitian merupakan suatu atribut atau sifat dari orang, obyek atau kegiatan yang memiliki variasi tertentu yang ditetapkan oleh peneliti untuk dipelajari dan ditarik kesimpulannya (Setiawan, 2013).

\section{HASIL DAN PEMBAHASAN}

Berdasarkan hasil dan
pengolahan data kuesioner
menggunakan program SPSS yang
telah dilakukan, sebagai sebuah
program olahdata statistik yang
powerfull (Setiawan, 2015). Dengan
demikian pembahasan terhadap
hipotesis penelitian adalah yang
menyatakan:

\section{A. Pengaruh Kualitas Produk terhadap Keputusan Pembelian}

Hasil uji signifikansi diperoleh nilai t-hitung sebesar 6,147 dan t-tabel 1,661 dengan demikian maka t-hitung lebih besar daripada t-tabel atau $(6,147>1,661)$. Dengan demikian hipotesis penelitian 1 diterima, $\mathrm{H} 0$ ditolak dan $\mathrm{H} 1$ diterima berarti ada hubungan yang positif dan signifikan antara Kualitas Produk dengan Keputusan Pembelian.

\section{B. Pengaruh Persepsi Harga terhadap Keputusan Pembelian} Hasil uji signifikansi parameter parsial $\mathrm{t}$ diperoleh nilai $\mathrm{t}$ hitung sebesar 2,989 dan $\mathrm{t}$ tabel 1,661 dengan demikian maka t-hitung lebih besar daripada $\mathrm{t}$-tabel atau $(2,989>1,661)$. Dengan demikian hipotesis penelitian 2 diterima, $\mathrm{H} 0$ ditolak dan $\mathrm{H} 1$ diterima berarti ada hubungan yang positif dan signifikan antara Persepsi Harga dengan Keputusan Pembelian.

\section{Pengaruh Promosi Media Luar Ruang terhadap Keputusan Pembelian}

Hasil uji signifikansi parameter parsial t diperoleh nilai t hitung sebesar 3,215 dan $\mathrm{t}$ tabel 1,661 dengan demikian maka $t$ hitung lebih besar daripada $t$ tabel atau $(3,215>1,661)$. Dengan demikian hipotesis penelitian 3 diterima, $\mathrm{H} 0$ ditolak dan $\mathrm{H} 1$ diterima berarti ada hubungan yang positif dan signifikan antara antara Promosi Media Luar Ruang dengan Keputusan Pembelian. 


\section{KESIMPULAN}

Berdasarkan hasil penelitian
dan pembahasan yang telah
dijelaskan, maka dari penelitian ini
dapat diambil kesimpulan. Dimana hal
ini merupakan jawaban dari
perumusan masalah yaitu:

1. Kualitas Produk berpengaruh positif dan signifikan terhadap Keputusan Pembelian

2. Persepsi Harga berpengaruh positif dan signifikan terhadap Keputusan Pembelian.

3. Promosi Media Luar Ruang berpengaruh positif dan signifikan terhadap Keputusan Pembelian

Berdasarkan pengujian secara serempak/simultan (Uji F), nilai $F$ hitung dari faktor Kualitas Produk (X1), Persepsi Harga (X2), dan Promosi Media Luar Ruang (X3) berpengaruh positif dan signifikan terhadap Keputusan Pembelian

\section{SARAN}

1. Jawaban responden $X 1$ masih terdapat jawaban sangat tidak setuju, tidak setuju dan kurang setuju pada bagian rasa, performs untuk mengganjal rasa lapar konsumen, dan mempresentasikan produk yang baik, maka Lapis Talas Sangkuriang harus meningkatkan kualitas yang berkenaan dengan hal-hal tersebut.

2. Jawaban responden $X 2$ masih terdapat jawaban sangat tidak setuju, maka Lapis Talas Sangkuriang harus membuat produk dengan harga ekonomis, seperti membuat produk dengan setengah ukuran yang sekarang dijual di pasaran.

3. Jawaban responden $X 3$ masih terdapat jawaban sangat tidak setuju, maka Lapis Talas Sangkuriang harus memperbaiki kualitas promosi dengan huruf dan pesan yang lebih mudah dipahami dengan gaya bahasa yang menarik.

4. Jawaban responden $Y$ masih terdapat jawaban tidak setuju dan kurang setuju, maka Lapis Talas Sangkuriang harus berinovasi untuk membuat Lapis Talas Sangkuriang menjadi Market Leader dalam urusan oleh-oleh khas Bogor, serta untuk menimbulkan 
keinginan pembelian ulang oleh

konsumen.

\section{DAFTAR PUSTAKA}

Ghanitama, Fifyanita. 2012. Analisis Pengaruh Harga, Kualitas Produk Dan Lokasi Terhadap Keputusan Pembelian (Studi pada Pembeli Produk Bandeng Juwana Erina di Semarang)". Semarang. Universitas Diponegoro.

Kottler, Philip, 2005. Manajemen Pemasaran : Analisis, Perencanaan, Implementasi dan Pengendalian. Terjemahan Bahasa Indonesia oleh Jaka Wasana. Jakarta : Erlangga

Kurniawan, Anggoro Dwi. 2012. Analisis Pengaruh Produk, Harga Dan Tempat Terhadap Keputusan Pembelian (Studi Harga Pada Kedai Amarta Semarang). Semarang. Universitas Diponegoro.

Machfoedz, Mahmud. 2005.

Pengantar Pemasaran Modern, AMP YKPN, Yogyakarta

Meliana, S., \& Setiawan, B. (2013). Pengaruh Kualitas Pelayanan dan Kepercayaan Konsumen Terhadap Keputusan Pembelian. IImiah Manajemen Kesatuan, 1, 247-254.

Natalia, Priccila. 2014. Pengaruh Periklanan dan Promosi Penjualan Terhadap Keputusan Pembelian. STIE Kesatuan Bogor.

Saladin, Djaslim. 2007. Manajemen Pemasaran Analisis, Perencanaan, Pelaksanaan dan Pengendalian. Edisi
Keempat. Bandung: CV Linda Karya

Setiawan, B. (2013). Menganalisa Statistik Bisnis dan Ekonomi dengan SPSS 21. Yogyakarta: Andi

Setiawan, B. (2015). Teknik Praktis Analisis Data Penelitian Sosial \& Bisnis dengan SPSS. Yogyakarta: CV Andi Offset

Setiawan, B. (2014). Customer Satisfaction Index Model on Three Level Of Socioeconomic Status In Bogor Case Study: Customer Satisfaction on Branded Cooking Oil Product. ASEAN Marketing Journal, 6(1). Retrieved October 23, 2018, from

http://journal.ui.ac.id/index.php/ amj/article/view/3609

Setiawan, B. (2018, April 7). A Critical Review of the Business Agility Literature in the Advancement of Information and Communication Technology. https://doi.org/10.31227/osf.io/x $\underline{4 \mathrm{kw}}$

Sugiyono. 2010. Metode Penelitian Pendidikan Pendekatan Kuantitatif, kualitatif, dan R\&D. Bandung: Alfabeta

Swastha, Basu dan Handoko T. Hani, 2008, Manajemen Pemasaran, Analisa Perilaku Konsumen, edisi pertama, cetakan keempat, Penerbit : BPFE, Yogyakarta

Swastha, Basu. \& Irawan. 2008. Manajemen Pemasaran Modern. Liberty. Jakarta. 
Tjiptono, Fandy. 2008. Strategi

Pemasaran. Yogyakarta : Andi

Offset

Saebani, Muhammad. 2016.

Pengaruh Kualitas Produk, Harga dan Promosi Terhadap

Keputusan Pembelian Pada PT. Batik Danar Hadi Surakarta.

Universitas Islam Batik

Surakarta.

Weenas, Jackson R. S. 2013. Kualitas Produk, Harga, Promosi dan

Kualitas Pelayanan

Pengaruhnya Terhadap

Keputusan Pembelian Spring

Bed Comforta. Universitas Sam

Ratulangi Manado. 